\title{
INDEX FOR \\ THE GENEVA PAPERS ON RISK AND INSURANCE 1976 THROUGH 1989*
}

ABBOTT, W. M.

- ASIR - A User's View, 7 (25), October 1982, 356-392.

ABRIL MARTOREL, Fernando

- Economic and Monetary Prospects: A Spanish Viewpoint, 5 (16), April 1980, 13 - 17.

ACKERMANN, Walter

- State, Security and Insurance, 3 (10), November 1978, 3-43.

AGMON, Tamir

- Introduction to: Measurement and Management of International Trade Risks, with Yehuda KAHANE, 11 (41), October 1986, $243-245$.

- Protection and Export Insurance: The Identification and the Measurement of International Trade Risks, 11 (41), October 1986, $249-254$.

AICKIN, Malcolm

- Legal and Cover Restrictions, 11, (39), April 1986, 157-167.

ALGERMISSEN, S. T.

- Seismic Hazard and Risk Assessment: Some Case Studies, with Karl STEINBRUGGE, 9 (30), January 1984, 8-26.

ALPEROVITCH, Annick

- De la Théorie à la Pratique de la Décision Médicale, 11, (40), July 1986, 230-234.

ANDERSON, Elizabeth

- Risk Assessment Issues Associated with Cleaning up Inactive Hazardous Waste Sites, with Paul CHROSTOWSKI and Judy VREELAND, 14 (51), April 1989, $104-119$.

ARGUELLES Y ARMADA, Jaime

- El Seguro - Hoy y Mañana, 8 (28), July 1983, 209-212.

ARROW, Kenneth

- Risk Allocation and Information: Some Recent Theoretical Developments, 3 (8), June 1978, 5-19.

- Can Additional Information Really Have Negative Welfare Effects - Reply, 4 (12), June 1979, 26.

ASKEW, Reubin

- Trade in Services and the World Economy, 8 (27), April 1983, 142 - 146.

BARRE, Raymond

- Introduction to: A Model for Measuring the Impacts of Inflation on Motor Insurance Business, 1 (1), January $1976,3$.

- L'Etat et la Demande de Sécurité, 8 (27), April 1983, 81 -87.

- The State and the Demand for Security, 8 (27), April 1983, 88-94.

BÉBÉAR, Claude

- Réflexions sur le Système Monétaire Européen: Discussion, with Georges MARTIN, Etienne DAVIGNON and Orio GIARINI, 5 (16), April 1980, 27-34.

BECKER, Fritz

- Functional Relations between General Economic Indicators, Premium Income and Claims Costs in Different Insurance Sectors, 4, (14), December 1979, 44-62.

BEENSTOCK, Michael

- Competitive Unemployment Insurance Pricing, 10 (34), January 1985, 23-31.

* Compiled by Wondon Lee, University of Alabama. 
BELLOY, Jean-Marc

- A Model for Measuring the Impacts of Inflation on Motor Insurance Business, with André GABUS, 1 (1), January 1976, 5-25.

BENJAMIN, Sidney

- Loadings for Insurance Premiums, 11 (39), April 1986, 110-125.

BERLINER, Baruch

- Some Thoughts on Uncertainty, the Transfer of Knowledge and Insurability, 9 (33), October $1984,380-395$.

- Large Risks and Limits of Insurability, 10 (37), October 1985, 313-329.

- Some Thoughts on Subjective Net Gross Insurability, 11, (39), April 1986, 91 -93.

- Subjective Determination of Limits of Insurability on the Grounds of Strategic Planning, with Hans BÜHLMANN, 11 (39), April 1986, 94-109.

- Insurability Issues Associated with Managing Existing Hazardous Waste Facilities, with Juerg SPUEHLER, 14 (51), April 1989, 169-195.

BERZ, Gerhard

- Research and Statistics on Natural Disasters in Insurance and Reinsurance Companies, 9 (31), April 1984, 135- 157.

BIAMONTE, Emilio

- Controlling the Risks from Liquefied Natural Gas, 7 (23), April 1982, 75-88.

DE BIEVRE, Aline

- Insurance for Civil Liability for Marine Oil Pollution Damages, with Jan BONGAERTS, 12 (43), April 1987, 145- 157.

BJÖRKLUND, Anders

- Unemployment Insurance: A Comment, 10 (34), January 1985, 32-35.

BLASSEL, Pierre

- Space Projects and the Coverage of Associated Risks, 10 (35), April 1985, 51-83.

BOHMAN, Harald

- A Mathematical Model of Insurance Business and How It May Be Used, 4 (11), January 1979, $34-39$.

- Reinsurance, Profitability and Insurability, 11 (39), April 1986, 126- 129.

DE BOISSIEU, Christian

- Uncertainty in Macro-Economics: A Comment, 13 (46), January 1988, 91-95.

BOISSONNADE, Auguste

- Seismic Vulnerability and Insurance Studies, with Haresh SHAH, 9 (32), July 1984, 223-254.

BONDI, Hermann

- The Changing Patterns of Risk, 13 (48), July 1988, 213-217.

BONGAERTS, Jan

- Insurance for Civil Liability for Marine Oil Pollution Damages, with Aline DE BIEVRE, 12 (43), April 1987, 145-157.

BORCH, Karl

- Introduction to: Essays in the Economic Theory of Risk and Insurance, 2 (5), February 1977, 3-8.

- Optimal Life Insurance, 2 (6), October 1977, 3 - 16.

- The Three Markets for Private Insurance, 6 (20), July 1981, 7-31.

- Risk, Incentives and Insurance: Some Comments, 8 (26), January 1983, 34-35.

- Static Equilibrium under Uncertainty and Incomplete Markets, 8 (29), October 1983, 307-315.

- Unemployment Insurance: Presentation of the Speaker, 10 (34), January 1985, 5.

- A Theory of Insurance Premiums, 10 (36), July 1985, 192-208. 
BOSANQUET, Nick

- Private Health Insurance in Britain and the National Health Service, 12 (45), October 1987, 350-357.

BRAMMERTZ, Ruth

- Moral Hazard, with Heinz MÜLlER, 11, (39), April 1986, 130- 144.

BRAUNSCHWEILER, Hans

- Security as a Service, 3 (7), January 1978, 42-55.

BREYER, Friedrich

- Can Additional Information Really Have Negative Welfare Effects? - A Note on Arrow's Risk Allocation and Information, 4 (12), June 1979, 23-25.

BRIYS, Eric

- On the Theory of Rational Insurance Purchasing in a Continuous-Time Model, 13 (47), April $1988,165-177$.

- Introduction to: On the Application of the Continuous-Time Theory of Finance to Financial Intermediation and Insurance, 14 (52), July 1989, 219-223.

BROWN, Margaret

- ASIR - The Advanced Simulation Model of Insurance and Re-Insurance Operation: An Introduction, with Lawrence GALITZ, 6 (19), April 1981, 85-96.

- Inflation and Interest Rates: A Research Study Using the ASIR Model, with Lawrence GALITZ, 7 (25), October 1982, 290-320.

- Fluctuating Exchange Rates: A Study Using the ASIR Model, with Lawrence GALITZ, 7 (25), October 1982, 321-355.

BÜCHNER, Georg

- Structural Problems Facing the German Insurance Industry, 8 (28), July 1983, 272-279.

BÜHLMANN, Hans

- Subjective Determination of Limits of Insurability on the Grounds of Strategic Planning, with Baruch BERLINER, 11 (39), April 1986, 94- 109.

BYATT, Ian

- The Discount Rate in the United Kingdom's Public Sector, 13 (48), July 1988, 248-251.

CANE, Peter

- Liability Rules and the Cost of Professional Indemnity Insurance, 14 (53), October 1989, 347-359.

CARTER, Robert

- Risk Management under Changing Economic Conditions, 7 (22), January 1982, 3-12.

- The State and the Demand for Security: Response, 8 (27), April 1983, 95-96.

- Public Policy and Insurability, 11 (39), April 1986, 145-156.

DE CARVALHO, Ruy

- Quelques Réflexions sur l'Assurance Maladie, 12 (45), October 1987, 370-376.

CASSIDY, A. A.

- AIDS and the Non-Life Insurance Market, 13 (49), October 1988, 332-341.

CHAPMAN, C. B.

- Contract Risk Analysis for Turnkey Project Bid: A Case Study, with Dale COOPER, 10 (37), October 1985, 293-305.

CHARPENTIER, Philippe

- Eléments pour une Analyse Economique de la Responsabilité du Fait des Produits, 3 (9), July 1978, 18-44.

CHEEK, Leslie

- Insurance Issues Associated with Cleaning up Inactive Hazardous Waste Sites, 14 (51), April $1989,120-148$. 
CHO, Dongsae

- The Pricing of Non-Independent Risks under Constant Absolute Risk Aversion, with Emilio VENEZIAN, 12 (42), January 1987, $21-33$.

- The Effects of an Expanded Underwriting Portfolio on Premium and Capital, 14 (50), January $1989,54-65$.

CHROSTOWSKI, Paul

- Risk Assessment Issues Associated with Cleaning up Inactive Hazardous Waste Sites, with Elizabeth ANDERSON and Judy VREELAND, 14 (51), April 1989, 104-119.

CLASSEN, Emil-Maria

- The Effects of Social Security on Saving: Comment, 5 (15), February 1980, 18-20.

CLEMEUR, Hugo

- The Three Markets for Private Insurance: Comment, 6 (20), July 1981, 44-47.

COOPER, Dale

- Contract Risk Analysis for Turnkey Project Bid: A Case Study, with C. B. CHAPMAN, 10 (37), October 1985, 293-305.

CORBY, Brian

- Implications for Insurers, 13 (48), July 1988, 218-228.

- On the Application of the Continuous-Time Theory of Finance to Financial Intermediation and Insurance: Response, 14 (52), July 1989, 263-265.

CORLIER, Freddy

- Simulation of an Automobile Portfolio, with Jean LEMAIRE and Dunia MUHOKOLO, 4 (11), January $1979,40-46$.

- The Three Markets for Private Insurance: Comment, with Jean LEMAIRE, 6 (20), July 1981, 32-35.

CREEDON, John

- Confronting AIDS: The Prospective of American Insurers, 13 (49), October 1988, 314-331.

CRESWELL, Donald

- The Nature and Importance of Economic Losses Due to the Utilisation of Containers in the Transportation Systems, with Jacques PEZIER and Stanley DAVENPORT, 4 (13), October 1979. 6-55.

CROCKFORD, Neil

- The Changing Face of Risk Management, 1 (2), August 1976, 10-15.

- The Bibliography and History of Risk Management: Some Preliminary Observations, 7 (23), April 1982, 169-179.

CUMMINS, David

- The State and the Demand for Security: Comments, 8 (27), April 1983, 97-104.

- The Impact of Rate Regulation in U.S. Property-Liability Insurance Markets: A Cross-Sectional Analysis of Individual Firm Loss Ratios, with Scott HARRINGTON, 12 (42), January 1987, $50-62$.

DAMARY, Roy

- A Survey of the Practice of Risk Management in West Europe Companies, 1 (2), August 1976, 27-55.

- A Survey of Consequential Loss Practices in Western Europe with Emphasis on the Chemical Industry, with Peter SCHMEER, 3 (9), July 1978, $45-65$.

- A Study of Recall Practices annong Manufacturers of Consumer Products, with Graham HURST, 7 (22), January 1982, 27-66.

- Risk and Insurance Management in the Packaged Goods Industry, 10 (37), October 1985, 235-267.

DAVENPORT, Stanley

- The Nature and Importance of Economic Losses Due to the Utilisation of Containers in the Transportation Systems, with Jacques PEZIER and Donald CRESWELL, 4 (13), October 1979, 6-55. 
DAVIGNON, Etienne

- Réflexions sur le Système Monétaire Européen: Discussion, with Georges MARTIN, Orio GIARINI and CLAUDE BÉBÉAR, 5 (16), April 1980, 27-34.

DEN BAKKER, E. K.

- Social Security in a European Perspective, with G. W. DE WIT, 8 (28), July 1983, 248-271.

DESIATA, Alfonso

- L'Assurance Italienne et l'Actuel Régime de Restrictions des Changes, 9 (32), July 1984, 299-303.

- The European Currency Unit and the Insurance Sector, 10 (35), April 1985, 112-119.

DEVOLDER, Pierre

- Le Taux d'Actualisation en Assurance, 13 (48), July 1988, 265-272.

DIACON, Stephen

- The Demand for UK Ordinary Life Insurance, 5 (17), June 1980, 3-22.

DICKINSON, Gerard

- International Insurance Transactions and the Balance of Payments, 2 (6), October 1977, 17-35.

- Underinsurance on a Portfolio of Property Exposure in an Inflationary Environment, with Leigh ROBERTS, 6 (21), October 1981, 3-19.

DICKSON, Gordon

- A Comparison of Attitudes Towards Risks among Business Managers, 7 (23), April 1982, 89-97.

DIONNE, Georges

- Adverse Selection and Repeated Insurance Contracts, 8 (29), October 1983, 316-332.

- The Effects of Insurance on the Possibilities of Fraud, 9 (32), July 1984, 304-321.

- Adverse Selection and Repeated Insurance Contracts: Reply, 9 (32), July 1984, 323-324.

- Increasing Risk and Self-Protection Activities, with Louis EECKHOUDT, 13 (47), April 1988. 132- 136 .

DODDS, J. C.

- Modelling the Investment Behaviour of British Life Offices 1963-1977, 4 (14), December 1979, 63-72.

DOHERTY, Neil

- Portfolio Adjustment in a Reinsurance Market, with Bob KORKIE, 5 (17), June 1980, 63-74.

DREZE, Jacques

- Human Capital and Risk-Bearing, 4 (12), June 1979, 5 -22.

- Inferring Risk Tolerance from Deductibles in Insurance Contracts, 6 (20), July 1981, 48-52.

DROMER, Jean

- On the Application of the Continuous-Time Theory of Finance to Financial Intermediation and Insurance: Réflexion, 14 (52), July 1989, 267-270.

DRUMMOND, M. F.

- Risky Choices in Medical Decision Making: A Comment, 11 (40), July 1986, 217-221.

EECKHOUDT, Louis

- L'Accroissement de Risque: Théorie et Application à la Production en Incertitude, 5 (17), June $1980,75-81$.

- Introduction to: Risky Choices in Medical Decision Making, 11 (40), July 1986, 195-196.

- Increasing Risk and Self-Protection Activities, with Georges DIONNE, 13 (47), April 1988. $132-136$.

EINAUDI, Mario

- The Investments of Insurance Companies: Difficulties New and Old, 3 (7), January 1978, 26-34.

EISEN, Roland

- Equilibrium in Risk-Bearing: The Principle of Equivalence - Different Implications of Alternative Interpretations, 4 (11), January 1979, 14-33. 
EISEN Roland

- Information and Observability - Some Notes on the Economics of Moral Hazard and Insurance, 6 (21), October 1981, 22-34.

ELLSWORTH, Robert

- Trends of Risk and Security Problems for States and Emerging Strategies for Coping with those Trends, 3 (7), January 1978, 16-25.

EMMINGER, Otmar

- The World's Monetary and Payments Situation, 8 (27), April 1983, 111-116.

FALCIGLIA, Antonio

- The Demand for Non-Life Insurance: A Consumption-Oriented Model, 5 (17), June 1980,45-53.

FARNY, Dieter

- Ansätze einer Betriebswirtschaftlichen Theorie des Versicherungsunternehmens, 2 (5), February 1977, 9-21.

FAURE, Michael

- Negligence, Strict Liability and Regulation of Safety under Belgian Law: An Introductory Economic Analysis, with Roger VAN DEN BERGH, 12 (43), April 1987, 95-114.

- Compulsory Insurance for Professional Liability, with Roger VAN DEN BERGH, 14 (53), October 1989, 308-330.

FELDSTEIN, Martin

- The Effect of Social Security on Saving, 5(15), February 1980, 4-17.

FENN, Paul

- Evaluating Irreplaceable Loss: Some Implications for Insurance and Liability Rules, 12 (43), April $1987,158-167$.

FERRARA, Giovanna

- A Model for Measuring the Impacts of Inflation on Motor Insurance Business: Comment, 1 (1), January 1976, 27-28.

- Real Rates of Return and Pension Funding: A Comment, 6 (18), January 1981, $64-65$.

FERRY, Christian

- L'Approche Empirique de la Demande d'Assurance-Vie, 2 (5), February 1977, 22-34.

FLUET, Claude

- Tarification et Interfinancement dans les Régimes Obligatoires d'Assurance-Automobile, 13 (47), April 1988, 115-131.

FORTUNA, Richard

- Legislative, Liability and Economic Strategies for Controlling Risks at Existing Hazardous Waste Facilities, and the Role and Use of Risk Assessment in a Preventive Program, 14 (51), April 1989, $196-206$.

FOSTER, Harold

- Reducing Vulnerability to Natural Hazards, 9 (30), January 1984, 27-56.

FRANCKX, Edouard

- The Three Markets for Private Insurance: Presentation, 6 (20), July 1981, 4-6.

FRANKLIN, Peter

- The Characteristics Approach and Its Application to Financial Liabilities, Financial Assets and Portfolio Choice, 4 (11), January 1979, 52-62.

- Some Considerations on the Activity of Insurance Business and its Relevance for a General Reassessment of Economic Theory: A Comment, 6 (21), October 1981, 104- 107.

FRIEDMAN, Don

- Natural Hazard Risk Assessment for an Insurance Program, 9 (30), January 1984, 57-128.

FRIEDMAN, Irving

- The Great Debate, 8 (27), April 1983, 117-126. 
FROMMKNECHT, Heinrich

- Erwartungen der Privaten Krankenversicherung an eine Strukturreform der Krankenversicherung, 12 (45), October 1987, 326-330.

FURSTENBERG, George von

- Social Security versus Private Saving and Insurance, 3 (10), November 1978, 44-49.

- Uncertainty in Macroeconomies: A Survey of its Treatment, 13 (46), January 1988, 5-11.

- Owning up to Uncertainty in Macroeconomics, with Jin-Ho JEONG, 13 (46), January 1988, 12-90.

GABUS, André

- A Model for Measuring the Impacts of Inflation on Motor Insurance Business, with Jean-Marc BELLOY, 1 (1), January 1976, 5-25.

- La Marge de Solvabilité et l'Egalité des Chances pour Accéder aux Marchés de l'Assurance NonVie, with Suzanne HAGEMANN, 6 (19), April 1981, 3-77.

GALE, David

- Equilibrium under Moral Hazard, 8 (26), January 1983, 36-37.

GALITZ, Lawrence

- ASIR - The advanced Simulation Model of Insurance and Re-Insurance Operations: An Introduction, with Margaret BROWN, 6 (19), April 1981, 85-96.

- The ASIR Model - An Introduction, 7 (25), October 1982, 279-289.

- A Research Study Using the ASIR Model, with Margaret BROWN, 7 (25), October 1982, $290-320$.

- Fluctuating Exchange Rates: A Study Using the ASIR Model, with Margaret BROWN, 7 (25), October 1982, 321-355.

GALLARDO, Guillermo

- The Markets for Disaster Insurance, 9 (31), April 1984, 175-187.

GANDHI, Devinder

- Stochastic Dominance: An Application to the Insurance Portfolio Decision, with Anthony SAUNDERS and Edmund SUGARS, 6 (21), October 1981, 51 - 62.

GASER, Norbert

- Productivity in Insurance with Special Reference to Telecommunications, 12 (44), July 1987, 264-272.

GASICH, Anthony

- Investment Strategy of Captive Insurers - Are Risk Managers Becoming Investment Managers?, with Moshe PORAT, 13 (49), October 1988, 377-402.

GEORGE, André

- Nature et Importance des Pertes Économiques dans l'Utilisation de l'Information en Europe en 1988, 1 (3), October 1976, 7-106.

- Les Risques de Pertes Indirectes Induites par les Systèmes Informatiques, 4 (13), October 1979, 56-80.

GIARINI, Orio

- A Macro-Economic Approach to Risk Management, I (2), August 1976, 5-9.

- Economics, Vulnerability and the Diminishing Returns of Technology, 2 (6), October 1977, $36-52$.

- Examples of Calculation of the Value Deducted, 4 (13), Octobcr 1979, 3-5.

- Réfluxions sur le Système Monétaire Européen: Discussion, with Georges MARTIN, Etienne DAVIGNON and Claude BÉBÉAR, 5 (16), April 1980, 27-34.

- Some Considerations on the Activity of Insurance Business and its Relevanee for a General Reassessment of Economic Theory, 6 (21), October 1981, 84-103.

- Développement Economique et Croissanee des Risques, 7 (22), January 1982, 13-26. 


\section{GIARINI, Orio}

- L'Incertitude de Newton à Heisenberg, un nouveau Paradigme pour l'Economique, 9 (33), October 1984, 396-409.

- Systèmes Economiques Complexes et Vulnèrabilité: Notes sur la Naissance de l'Économie de Service, 12, (44), July 1987, 171- 179.

- The Cultural Foundation of the Brand Image of Insurance, 13 (48), July 1988, 229-243.

GILL, J.

- Export Credit Insurance - Why Government, 11 (41), October 1986, 265-268.

GLEJSER, Herbert

- Le Taux d'Actualisation en Belgique, 13 (48), July 1988, 257-264.

GOLLIER, Christian

- Risk-Sharing on the Labour Market: How to Treat Young Generations?, 14 (50), January 1988, $26-53$.

GOUGEON, Patrick

- Assurance et Prévention: Unc Approche Portefeuille, 8 (29), October 1983, 350-370.

GRASES, Josè

- Expected Building Losses Caused by Earthquakes, 10 (35), April 1985, 84-99.

GRAVELLE, Hugh

- Accidents, Taxes, Liability Rules and Insurance, 12 (43), April 1987, 115-131.

- Accidents and the Allocation of Legal Costs with an Uninformed Court, 14 (50), January 1989, $11-25$.

GREENBERG, Maurice

- Document: Financing the Clean-up of Hazardous Waste, 14 (51), April 1989, $207-212$.

GUSTAVSON, Sandra

- Risk-Return Tradeoff, Income Measurement and Capital Asset Pricing for life Insurers: An Empirical Investigation, with Cheng-F. Lee, 11 (38), January 1986, 23-43.

HAGEMANN, Suzanne

- Le Troisième Age: Problèmes et Perspectives, 6 (18), January 1981, 74-108.

- La Marge de Solvabilité et l'Egalite des Chances pour Acceder aux Marchés de l'Assurance NonVie, with Andre GABUS, 6 (19), April 1981, 3-77.

HALLER, Matthias

- Les Objectifs du Risk Management, 1 (2), August 1976, 16-26.

- New dimensions of Risks: Consequences for Management, 3 (7), January 1978, 3-15.

- "The Third Wave" - Also in Insurance?, 8 (27), April 1983, 158- 174.

HANSSON, Ingemar

- Moral Hazard and Safety Regulation, with Göran SKOGH, 12 (43), April 1987, 132 - 144.

HARRINGTON, Scott

- Discussion on Adverse Selection, 8 (29), October 1983, 333-335.

- The Impact of Rate Regulation in U.S. Property-Liability Insurance Markets: a Cross-Sectional Analysis of Individual Firm Loss Ratios, with David CUMMINS, 12 (42), January 1987, 50-62.

HART, Oliver

- Risk, Incentives and Insurance: Comment, 8 (26), January 1983, 38-41.

HASHEK, H. H.

- Export Credit Insurance and the Debt Crisis, 11 (41), October 1986, 285-291.

HAWAWINI, Gabriel

- An Uncertainty Model of the Professional Partnership, 10 (36), July 1985, 174 - 191.

HAYES, R. W.

- Management of Risk in Engineering: Risk Allocation through Contractual Approaches, 10 (37), October $1985,306-312$. 
HEAD, George

- Continuing Evolution of the Risk Management Function and Education in the United States, 7 (23), April 1982, 180-186.

HELLWIG, Martin

- Moral Hazard and Monopolistically Competitive Insurance Markets, 8 (26), January 1983, 44 - 71.

HELTEN Elmar

- Business Cycles and Insurance, 2 (6), October 1977, 53-75.

HEMMING, Richard

- Real Rates of Return and Pension Funding - Some Preliminary Considerations, 6 (18), January 1981, 51-63.

- Real Rates of Return and Pension Funding: Reply, 6 (18), January 1981, 66-67.

HENDERSON, Hazel

- Risk, Uncertainty and Economic Futures, 3(9), July 1978, 3 - 17.

HENRY, Claude

- Assurance et Information Imparfaite, 6(20), July 1981, 41-43.

HEY, G. B.

- Motor Insurance in the United Kingdom: A Description and an Appraisal, with John HEY, 12 (44), July 1987, 226-239.

HEY, John

- No Claim Bonus?, 10 (36), July 1985, 209-228.

- Motor Insurance in the United Kingdom: A Description and an Appraisal, with G. B. HEY, 12 (44), July 1987, 226-239.

HOFMANN, J.

- Adverse Selection and Repeated Insurance Contracts: Some Comments, 9 (32), July 1984, 322-323.

HOOBROECKX, Jan

- The Boundaries of Credit Insurance: A Comment, 11 (41), October 1986, 292-293.

HURST, Graham

- A Study of Recall Practices among Manufacturers of Consumer Products, with Roy DAMARY, 7 (22), January 1982, 27-66.

JEONG, Jin-Ho

- Owning up to Uncertainty in Macroeconomics, with George von FURSTENBERG, 13 (46), January 1988, 12-90.

JONES-LEE, Michael

- Natural Disasters: A Comparison of Alternative Methods for Evaluating Preventive Measures, 9 (31), April 1984, 188-205.

- The Value of Life and Safety: A Survey of Recent Developments, 10 (36), July 1985, 141 - 173.

KAHANE, Yehuda

- Reinsurers' Investment and Underwriting Portfolios and the Exchange Rates Risk, 4 (11), January $1979,63-67$.

- Solidity, Leverage and the Regulation of Insurance Companies, 4 (14), December 1979, 3 - 19.

- Introduction to: Measurement and Management of International Trade Risks, with Tamir AGMON, 11 (41), October 1986, 243-245.

- Insurance and Risk Management of Foreign Trade Risks, 11 (41), October 1986, 274-284.

- Eartquake Risk and Insurance - Policy Considerations: The Israeli Case, 13 (47), April 1988, 137- 164.

KALUZA, Bernd

- Some Considerations of the Empirical Research of Goal Systems of Insurance Companies, 7 (24), July $1982,248-263$. 
KARNIK, Vit

- Existing Recommendations and Definitions on Disaster Insurance, 9 (30), January 1984, 3-7.

KARTEN, Walter

- The New "Schwankungsrückstellung" in Annual Statements of German Insurer - An Application of the Theory of Risk?, 5(17), June 1980, 54-62.

KEILIS-BOROK, V.I.

- Seismic Risk for the Largest Cities of the World, with T. L. KRONROD and G. M. MOLCHAN, 9 (32), July 1984, 255-270.

KESSLER, Denis

- Social Security and Saving: A Tentative Survey, with André MASSON and Dominique STRAUSS-KAHN, 6 (18), January 1981, 3-50.

- The Four Pillars of Retirement, 13 (49), October 1988, 342-349.

KIRSCHEN, Etienne-Sadi

- Problèmes Actuels de l'Actualisation, 13 (48), July 1988, 244-247.

KITTREDGE, John

- Future Perspectives of Health Insurance: A Comment, 12 (45), October 1987, 308 -313.

KLOMAN, Felix

- The Captive Insurance Phenomenon: A Cautionary Tale?, with Hugh ROSENBAUM, 7 (23), April 1982, 129-151.

KORKIE, Bob

- Portfolio Adjustment in a Reinsurance Market, with Neil DOHERTY, 5 (17), June 1980, 63-74.

KORNIS, Karl

- Die künftige Entwicklung des Versicherungsmarktes aus der Sicht der Praxis, 8 (28), July 1983 , $201-208$.

KRAMAR, Luciano

- Quelques Aspects de l'Assurance dans les Relations Economiques Internationales, 3 (9), July 1978, 66-82.

KREISKY, Bruno

- Thoughts on the Policy of Detente in Europe, 5 (16), April 1980, 5- 12.

KRONROD, T. L.

- Seismic Risk for the Largest Cities of the World, with V. I. KEILIS-BOROK and G. M. MOLCHAN, 9 (32), July 1984, 255-270.

KUNREUTHER, Howard

- Causes of Underinsurance against Natural Disasters, 9 (31), April 1984, 206-220.

- Problems and Issues of Environmental Liability Insurance, 12 (44), July 1987, 180 - 197.

- Towards an Integrated Waste Management Program, 14 (51), April 1989, 99-103.

KYLEN, Brian

- The Composition of a Consequential Loss from a Strategic Perspective, 7 (23), April 1982, 98-113.

LAFFONT, Jean-Jacques

- Asymétrie d'Information et les Trois Marchés de l'Assurance, 6 (20), July 1981, 36 -40.

DE LARRAMENDI Y MONTIANO, Ignacio

- Social Security and Private Sickness Insurance in Spain, 12 (45), October 1987, 364-369.

LARSEN, Norma

- Optimum Retirement Age, with August RALSTON, 7 (24), July 1982, 191-206.

LAUNOIS, Robert

- Les Réseaux de Soins Coordonnés: un Projet de Réforme du Système de Soins Français, 12 (45), October 1987, 343-349. 
LEE, Cheng-F.

- Risk-Return Tradeoff, Income Measurement and Capital Asset Pricing for Life Insurers: An Empirical Investigation, with Sandra GUSTAVSON, 11 (38), January 1986, 23 - 43.

LEEPIN, Peter

- Risk, Incentives and Insurance: Comment, 8 (26), January 1983, $42-43$.

LEMAIRE, Jean

- Simulation of an Automobile Portfolio, with Fredy CORLIER and Dunia MUHOKOLO, 4 (11), January $1979,40-46$.

- The Three Markets for Private Insurance: Comment, with Fiedy CORLIER, 6 (20), July 1981, $32-35$.

LEONARD, Herman

- Public Insurance Provision and Non-Market Failures, with Richard ZECKHAUSER, 8 (27), April 1983, 147-157.

LESSARD, Donald

- The Management of International Trade Risks, 11 (41), October 1986, 255-264.

LIBASSI, Peter

- Integrating the Elder into the Labor Force: Consequences and Experience for Insurance, 13 (49), October 1988, 350-360.

LINDBAEK, Jannik

- Norwegian Property and Casualty Insurance Towards 1990, 8 (28), July 1983, 298-303.

- Introduction to: Unemployment Insurance, 10 (34), January 1985, 3-4.

LITTON, R. A.

- Crime and Insurance, 12 (44), July 1987, 198-225.

LONG, Oliver

- Réflexions sur les Relations Commerciales Internationales, 8 (27), April 1983, 136-141.

LONGO, Antonio

- Résultats et Perspectives de l'Assurance Vie en Italie, 8 (28), July 1983, 286-291.

LOUBERGÉ, Henri

- The Teaching of Risk and Insurance Economics in Europe, 2 (4), January 1977, 5 - 64.

- Reinsurance and Foreign Exchange Risk, 4 (14), December 1979, 20-43.

- Private Initiative and Public Intervention on the Market for Export Credit Insurance, with Pierre MAURER, 10 (35), April 1985, 100-111.

- Uncertainty in Macroeconomics and the Microeconomics of Uncertainty, 13 (46), January 1988. $96-99$.

MACMINN, Richard

- A Financial Theory of the Insurance Firm under Uncertainty and Regulatory Constraints, with Robert WITT, 12 (42), January 1987, 3-20.

MACHNESS, Yaffa

- Indexed and Non-Indexed Insurance, 7 (24), July 1982, 264-275.

MAIN, Brian

- Business Insurance and Large, Widely-Held Corporations, 7 (24), July 1982, 237-247.

MALINVAUD, Edmond

- Unemployment Insurance, 10 (34), January 1985, 6-22.

MANN, Jonathan

- Global AIDS: a Status Report, 13 (49), October 1988, 303-313.

MARCHANT, Eric

- Analysis of Recovery from Fire Risk in Industry and Commerce, 10 (37), October 1985, 268-292.

MARTIN, Georges

- Réflexions sur le Système Monétaire Européen: Discussion, with Etienne DAVIGNON, Orio GIARINI and Claude BÉBÉAR, 5 (16), April 1980, 27-34. 
MARTIN, Georges

- Economics and Risk: Remark, 5 (16), April 1980, 43 - 44

- Introduction to: The Three Markets for Private Insurance, 6 (20), July 1981, 3.

- Inflation et Assurance, 8 (28), July 1983, 227-236.

MASSON, André

- Social Security and Saving: A Tentative Survev, with Denis KESSLER and Dominique STRAUSS-KAHN, 6 (18), January 1981, 3-50.

MAST, Hans

- Investment Management in an Inflationary World, 8 (27), April 1983, 127-135.

MAURER, Pierre

- Private Initiative and Public Intervention on the Market for Export Credit Insurance, with Henri LOUBERGÉ, 10 (35), April 1985, 100-111.

MCBARNET, Doreen

- The "Crisis" in Professional Liability Insurance, with Christopher WHELAN, 14 (53), October 1989, 296-307

MERTON, Robert

- On the Application on the Continuous-Time Theory of Finance to Financial Intermediation and Insurance, 14 (52), July 1989, 225-261.

MOFFET, Denis

- The Risk-Sharing Problem, 4 (11), January 1979, 5-13.

MOLCHAN, G. M.

- Seismic Risk for the Largest Cities of the World, with V. I. KEILIS-BOROK and T. L. KRONROD, 9 (32), July 1984, 255-270.

MORDI, Obi

- Empirische Darstellung des Versicherungsoutputs in Versicherungsgarantieeinheiten, with Franz THOLE, 12 (44), July 1987, 240-246.

- Outputmessung in der Versicherungswirtschaft - Konzeptionelle wirtschaftliche und versicherungstechnische Überlegungen -, 12 (44), July 1987, 247-263.

MORIMIYA, Yasushi

- Demand for Natural Disaster Insurance, 9 (32), July 1984, 27 I - 279.

MOSER, Warren

- The Evolution of Health Care Delivery in American Industry, 12 (45), October 1987, 297-307.

MUHOKOLO, Dunia

- Simulation of an Automobile Portfolio, with Freddy CORLIER and Jean LEMAIRE, 4 (11), January $1979,40-46$.

MÜLLER, Heinz

- Moral Hazard, with Ruth BRAMMERTZ, 11 (39), April 1986, 130-144.

MÜLLER, Wolfgang

- Theoretical Concepts of Insurance Production, 6 (21), October 1981, 63-83.

MUNCH DANZON, Patricia

- Rating Bureaus in U.S. Property-Liability Insurance Markets: Anti or Pro-Competitive?, 8 (29), October 1983, 371-402.

MUNKHAMMAR, Åke

- Catastrophe Insurance, with Robert THEMPTANDER, 9 (31), April 1984, 131 - 134.

NEAVE, Julius

- Introduction to: Aspects of Risk and Vulnerability in European Economies, 5 (16), April 1980, $3-4$.

- The Changed Face of Reinsurance, 8 (28), July 1983, 185-191.

NEUMANN, Manfred

- Owning up to Uncertainty in Macroeconomics: A Comment, 13 (46), January 1988, 100 - 103. 
NICKELL, Stephen

- Unemployment Insurance and Wages, 10 (34), January 1985, 36-38.

NIERHAUS, Fedor

- A Strategic Approach to Insurability of Risks, 11 (39), April 1986, 83-90.

NIETO DE ALBA, Ubaldo

- Economics and Risk, 5 (16), April 1980, 38-42.

OLSON, Douglas

- An Overview of Risk Management, with John SIMKISS, 7 (23), April 1982, 114-128.

OUGHTON, David

- Expanding Tort Liability in English Law and Compulsory Insurance for Professional Risks, 14 (53), October 1989, 331-346.

OUTREVILLE, Jean-François

- Dėpenses d'Assurances, Primes Encaissées: une Approche Macroéconomique, 5 (17), June 1980, $23-44$.

- Les Operations des Compagnies d'Assurance IARD: Identification de Modèles et Simulation d'Hypothèses de Conjoncture Economique, 6 (21), October 1981, 34-50.

PADOA, Fabio

- Introduction to: The Effect of Social Security on Saving, 5 (15), February 1980, 3.

- L'Assurance et l'Intėgration Monetaire Europeenne, 5 (16), April 1980, 35 - 37.

- Introduction à: L'Etat et la Demande de Sécuritè dans les Sociètès Contemporaines, 8 (27), April 1983, 79-80.

- Genève, Dix Ans Après, 8 (28), July 1983, 179 - 184.

- Reflections on Uncertainty in Economics: Comment, 9 (33) October 1984, 366-369.

PASSET, Renè

- The Paradigms of Uncertainty, 9 (33), October 1984, 370-379.

PAULY, Mark

- Optimal Public Subsidies of Nursing Home Insurance in the United States, 14 (50), January 1989, 3-10.

PETRILLI, Giuseppe

- La Prèvoyance dans l'Economie Italienne, 3 (10), November 1978, 67-72.

PEZIER, Jacques

- The Nature and Importance of Economic Losses Due to the Utilisation of Containers in the Transportation Systems, with Donald CRESWELL and Stanley DAVENPORT, 4 (13), October 1979, $6-25$.

PITELIS, Christos

- The Substitutability between Discretionary and Contractual Saving and the "Propensity" to Save Profit and Wage Income in the UK, 12 (42), January 1987, 37-49.

PORAT, Moshe

- Investment Strategy of Captive Insurers - Are Risk Managers Becoming Investment Managers?, with Anthony GASICH, 13 (49), October 1988, 377-402.

PORRO, Bruno

- Natural Disaster Insurance, Problems of Capacity and Solvency, 9 (31), April 1984, $158-166$.

PRIETO PEREZ, Eugenio

- Determination of the Amounts Available for Long-Term Investment in an Insurance Company, 4 (11), January 1979, 47-51.

RADNER, Alfred

- Soziale Sicherheit und Staatsfinanzen, 3 (10), November 1978, 85-95.

RALSTON, August

- Optimum Retirement Age, with Norma LARSEN, 7 (24), July 1982, 191 - 206. 
RAMEY, Thomas

- Future Perspectives of Health Insurance, 12 (45), October 1987, $291-296$.

RATCLIFF, Anthony

- The Impact of Productivity in the Insurance Cycle, 8 (28), July 1983, 237-243.

REITZ, Brigitte

- On the Development of Group Insurance and Collective Saving in the Federal Republic of Germany and in Great Britain, 3 (10), November 1978, 50-66.

ROBERTS, John

- Underwriting in a Competitive Market, 8 (28), July 1983, 244-247.

ROBERTS, Leigh

- Underinsurance on a Portfolio of Property Exposures in an Inflationary Environment, with Gerard DICKINSON, 6 (21), October 1981, 3-19.

ROMAGNOLI, Pier

- The Italian Insurance Market, 8 (28), July 1983, 280-285.

ROSA, André

- A Model for Measuring the Impacts of Inflation on Motor Insurance Business: Comment, 1 (1), January 1976, 26.

ROSA, Jean-Jacques

- La Demande d'Assurance Non-Vie: l'Etat Actuel de la Théorie, 2 (5), February 1977, $35-42$.

- Introduction to: Human Capital and Risk-Bearing, 4 (12), June 1979, 3-4.

ROSENBAUM, Hugh

- The Captive Insurance Phenomenon: A Cautionary Tale?, with Felix KLOMAN, 7 (23), April $1982,129-151$

ROSS, Stephen

- On the Application of the Continuous-Time Theory of Finance to Financial Intermediation and Insurance: Comment, 14 (52), July 1989, $271-273$.

SAILLY, J.C.

- Risky Choices in Medical Decision Making: A Comment, 11 (40), July 1986, 222-229.

SALISBURY, Dallas

- Changing Health Care in the United States, 12 (45), October 1987, 277-290.

SALVATOR, Maurice

- Managing Insurance Risks: Research into Price, 7 (23), April 1982, 152 - 168.

SAUNDERS, Anthony

- Stochastic Dominance: An Application to the Insurance Portfolio Decision, with Devinder GANDHI and Edmund SUGARS, 6 (21), October 1981, $51-62$.

SCHIEREN, Wolfgang

- The Economic Significance of the Private Insurance Business Sector, 8 (28), July 1983, 192-200.

SCHLESINGER, Harris

- Compulsory Insurance and Consumer Welfare: A State-Claims Approach, 11 (38), January 1986, 17-22.

- Social Security as a Wage Subsidy over the Life Cycle, 11 (38), January 1986, 61 - 76.

SCHLOSS, Aran

- Some Observations on the Use of Social and Political Indicators in International Trade Risk Assessment, 11 (41), October 1986, 294-307.

SCHMEER, Peter

- A Survey of Consequential Loss Practices in Western Europe with Emphasis on the Chemical Industry, with Roy DAMARY, 3 (9), July 1978, 45-65.

SCHMIDT, Reimer

- Science and Practice of Insurance, 8 (28), July 1983, 213-226.

- Introduction to: Problems and Perspectives of Health Insurance, 12 (45), October 1987, 275-276. 
SCHMIDT, Reimer

- Praktische Auswirkungen der Dienstleistungsfreiheit auf die Versicherung in der EG, 14 (5) supp.) April 1989, 3-13.

- Consequences of the Freedom of Services on Insurance in the European Community, 14 (51 supp.), April 1989, 14-23.

SCHOTT, Francis

- Capital Investment and Saving: A Review, 6 (18), January 1981, 68-73.

SCHROATH, Frederick

- Mode of Foreign Market Entry: An Analysis of the Property and Liability Insurance Industry, 13 (49), October 1988, 361-376.

SCHROEDER, Peter

- Environmental Risk Management: The Experience of a European Insurer, 14 (51), April 1989, $160-168$.

SCHULENBURG, Matthias Graf von der

- No Claim Bonus?: A Comment, 10 (36), July 1985, 229-231.

- Optimal Insurance Purchasing in the Presence of Compulsory Insurance and Uninsurable Risks, 11 (38), January 1986, 5-16.

- Recent Developments of Health Insurance in West Germany, 12 (45), October 1987, 331 - 342.

SCHWEBLER, Robert

- Identification and Quantification of the Overall Impact in the Federal Republic of Germany, 9 (32), July $1984,280-298$.

- Market Development and Market Structure of Legal Expenses Insurance in Germany, 10 (35), April 1985, 120-133.

SEIFF, James

- Risk Management Strategies Used in Cleaning up Hazardous Waste Sites, with Thomas VOLTAGGIO, 14 (51), April 1989, 149-159.

SHAH, Haresh

- Seismic Vulnerability and Insurance Studies, with Auguste BOISSONNADE, 9 (32), July 1984, 223-254.

SHAVELL, Steven

- A Note on the Incentive to Reveal Information, 14 (50), January 1989, 66-74.

SIMKISS, John

- An Overview of Risk Management, with Douglas OLSON, 7 (23), April 1982, 114- 128.

SKOGH, Göran

- Introduction to: Liability, Insurance and Safety Regulation, 12 (43), April 1987, 91-94.

- Moral Hazard and Safety Regulation, with Ingemar HANSSON, 12 (43), April 1987, 132 - 144.

- Professional Liability Insurance in Scandinavia, 14, (53), October 1989, 360-370.

SOLNIK, Bruno

- On the Application of the Continuous-Time Theory of Finance to Financial Intermediation and Insurance: Comment, 14 (52), July 1989, 275-278.

SPUEHLER, Juerg

- Insurability Issues Associated with Managing Existing Hazardous Waste Facilities, with Baruch BERLINER, 14 (51), April 1989, 169-195.

STEIGUM, Erling

- Unemployment Insurance, Payroll Taxes and Employment, 10 (34), January 1985, 39-45.

STEINBRUGGE, Karl

- Seismic Hazard and Risk Assessment: Some Case Studies, with S. T. ALGERMISSEN, 9 (30), January 1984, 8-26.

STERK, Hans-Peter

- Deductibles from a Risk-Theoretical Point of View, 5 (17), June 1980, 82-95. 
STIGIJITZ, Joseph

- Risk, Incentives and Insurance: The Pure Theory of Moral Hazard, 8 (26), January 1983, 4-33.

- On the Theory of Social Insurance, 8 (27), April 1983, $105-110$.

STRAUSS-KAHN, Dominique

- Social Security and Saving: A Tentative Survey, with Denis KESSLER and André MASSON, 6 (18), January 1981, 3-50.

SUGARS. Edmund

- Stochastic Dominance: An Application to the Insurance Portfolio Decision, with Devinder GANDHI and Anthony SAUNDERS, 6 (21). October 1981, 51-62.

SZPIRO, George

- The Hypotheses of Absolute and Relative Risk Aversion: An Empirical Study Using Cross-Section Data, 8 (29), October 1983, 336-349.

- The Decision to Buy or Sell Insurance under Constant Relative Risk Aversion, 12 (42), January 1987, 34-36.

THEMPTANDER, Robert

- Catastrophe Insurance, with Åke MUNKHAMMAR, 9 (31), April 1984, 131-134.

THOLE, Franz

- Empirische Darstellung des Versicherungsoutputs in Versicherungsgarantieeinheiten, with Obi MORDI, 12 (44), July 1987, 240-246.

THOMEE, Friedrich

- Industrial Management Flexibility in Times of Economic Change, 3 (7), January 1978, 35-41.

THORNE. Nigel

- Reinsurance and Natural Disasters, 9 (31), April 1984, 167-174.

TIMMER, Hans

- Die Stellung der Privaten Krankenversicherung im System der Sozialen Sicherheit in der Bundesrepublik Deutschland, 12 (45), October 1987, 321-325.

TRIFFIN, Robert

- Réflexions sur le Système Monétaire Européen, 5 (16), April 1980, 18-26.

URRUTIA, Jorge

- Price Competition, Regulation, and Systematic Underwriting Risk in Automobile Insurance, with Robert WITT, 8 (29). October 1983, 403 - 429.

- The Capital Asset Pricing Model and the Determination of Fair Underwriting Returns for the Property-Liability Insurance Industry, 11 (38), January 1986, 44-60.

VAN DEN BERGH, Roger

- Negligence, Strict Liability and Regulation of Safety under Belgian Law: An Introductory Economic Analysis, with Michael FAURE, 12 (43), April 1987, 95-114.

- Compulsory Insurance for Professional Liability, with Michael FAURE, 14 (53), October 1989, 308-330.

VAN DEN BERGHE, Lutgart

- Insurance in the National Accounts: A Case-Study of France, 2 (6), October 1977, 78-89.

VAN NAMEN. Philippe

- Underinsurance on a Portfolio of Property Exposures in an Inflationary Environment: Comments, 6 (21), October 1981, 20-21.

VENEZIAN, Emilio

- The Pricing of Non-Independent Risks Under Constant Absolute Risk Aversion, with Dongsae CHO. 12 (42), January 1987, 21-33.

VERDEIL, Guy

- Les Perspectives d'Evolution de l'Assurance Vie en France, 8 (28), July 1983, 292-297.

VISCHER, Heinz

- Introduction to: Risk, Incentives and Insurance, 8 (26), January 1983, 3. 
VITALI, Lucia

- The Expansion of Social Security in Italy, 3 (10), November 1978, 73-84.

VOLTAGGIO, Thomas

- Risk Management Strategies Used in Cleaning up Hazardous Waste Sites, with James SEIF, 14 (51), April 1989, 149-159.

VREELAND, Judy

- Risk Assessment Issues Associated with Cleaning up Inactive Hazardous Waste Sites, with Elizabeth ANDERSON and Paul CHROSTOWSKI, 14 (51), April 1989, $104-119$.

WALLEN, Axel

- Some Comments on the Present Consensus Arrangement and its Implications to World Trade, 11 (41), October 1986, 269-273.

WALLISER, Bernard

- Le Taux d'Actualisation en France, 13 (48), July 1988, 252-256.

WARD, Donald

- The Management of International Trade Risks: The Role of the Berne Union, 11 (41), October 1986, 246-248.

WEINSTEIN, Milton

- Risky Choices in Medical Decision Making: A Survey, 11 (40), July 1986, 197-216.

WEISSKOPF, Walter

- Reflections on Uncertainty in Economics, 9 (33), October 1984, 335-360.

WELZEL, Hans

- The Proposal for a Community Directive on the Accounts of Insurance Undertakings, 13 (48), July 1988, 273-283.

WHELAN, Christopher

- Law and Economics of Professional Liability lnsurance: Preface, 14 (53), October 1989, 295.

- The "Crisis" in Professional Liability Insurance, with Doreen MCBARNET, 14 (53), October 1989, 296-307.

WILMOT, Tom

- European Fire Costs: The Wasteful Statistical Gap, 4 (13), October 1979, 85-101.

DE WIT, G. W.

- Social Security in a European Perspective, with E. K. DEN BAKKER, 8 (28), July 1983, 248 - 271.

- Discussions about Health Insurance in Holland, 12 (45), October 1987, 358-363.

WITT, Robert

- Price Competition, Regulation, and Systematic Underwriting Risk in Automobile Insurance, with Jorge URRUTIA, 8 (29), October 1983, 403-429.

- A Financial Theory of the Insurance Firm under Uncertainty and Regulatory Constraints, with Richard MACMINN, 12 (42), January 1987, 3-20.

WOODWARD, Douglas

- The Developing Threat from Arson, 13 (48), July 1988, 284-297.

ZAJDLIC, Wlodek

- Economists in the Insurance Industry, 4 (14), December 1979, $73-79$.

ZECKHAUSER, Richard

- Public Insurance Provision and Non-Market Failures, with Herman LEONARD, 8 (27), April $1983,147-157$

ZWEIFEL, Peter

- Demand for Supplementary Health Insurance in Switzerland: A Theoretical and Empirical Investigation, 7 (24), July 1982, 207-236.

- HMOs and Some European Alternatives, 12 (45), Octobcr 1987, 314-320. 